University of Montana

ScholarWorks at University of Montana

$11-2006$

\title{
The Effects of Postfire Salvage Logging on Cavity-Nesting Birds
}

Richard L. Hutto

University of Montana - Missoula, hutto@mso.umt.edu

Susan M. Gallo

Follow this and additional works at: https://scholarworks.umt.edu/biosci_pubs

Part of the Biology Commons

Let us know how access to this document benefits you.

\section{Recommended Citation}

Hutto, Richard L. and Gallo, Susan M., "The Effects of Postfire Salvage Logging on Cavity-Nesting Birds" (2006). Biological Sciences Faculty Publications. 266.

https://scholarworks.umt.edu/biosci_pubs/266

This Article is brought to you for free and open access by the Biological Sciences at ScholarWorks at University of Montana. It has been accepted for inclusion in Biological Sciences Faculty Publications by an authorized administrator of ScholarWorks at University of Montana. For more information, please contact scholarworks@mso.umt.edu. 


\title{
THE EFFECTS OF POSTFIRE SALVAGE LOGGING ON CAVITY-NESTING BIRDS
}

\author{
Richard L. HutTo ${ }^{1,3}$ AND SUSAN M. GALLO ${ }^{2}$ \\ ${ }^{1}$ Avian Science Center, Division of Biological Sciences, University of Montana, Missoula, MT 59812 \\ ${ }^{2}$ Maine Audubon, Falmouth, ME 04105
}

\begin{abstract}
We investigated the effects of postfire salvage logging on cavity-nesting birds by comparing nest densities and patterns of nest reuse over a three-year period in seven logged and eight unlogged patches of mixed-conifer forest in the Blackfoot-Clearwater Wildlife Management Area, Montana. We found 563 active nests of 18 cavity-nesting birds; all species were found nesting in the uncut burned forest plots, but only eight nested in the salvage-logged plots. All except one species nested at a higher density in the unlogged areas, and half of the species were significantly more abundant in the unlogged plots. Every timber-drilling and timber-gleaning species was less abundant in the salvagelogged plots, including two of the most fire-dependent species in the northern Rocky Mountains-American Three-toed (Picoides dorsalis) and Black-backed (P. arcticus) Woodpeckers. Lower abundances in salvage-logged plots occurred despite the fact that there were still more potential nest snags per hectare than the minimum recommended number needed to support maximum densities of primary cavity-nesters, which suggests that reduced woodpecker densities are more related to a reduction in food (wood-boring beetle larvae) than to nest-site availability. Because cavities were present in only four of 244 randomly selected trees, and because frequency of cavity reuse by secondary cavitynesters was higher in salvage-logged than in unlogged plots, nest-site limitation may be a more important constraint for secondary cavity-nesters in salvage-logged areas. These results suggest that typical salvage logging operations are incompatible with the maintenance of endemic levels of most cavity-nesting bird populations, especially populations of primary cavity-nesting species.
\end{abstract}

Key words: Black-backed Woodpecker, cavity-nesting birds, fire, healthy forests, salvage logging.

Efectos de la Extracción Forestal Post-Incendio sobre las Aves que Anidan en Cavidades

Resumen. Investigamos los efectos de la extracción forestal post-incendio sobre las aves que anidan en cavidades por medio de una comparación de la densidad de nidos y los patrones de su reutilización. El estudio se realizó durante un periodo de tres años, en fragmentos de bosque mixto de coníferas quemados con y sin extracción forestal (siete y ocho fragmentos, respectivamente) en el Area de Manejo de Fauna Silvestre BlackfootClearwater, Montana. Encontramos 563 nidos activos pertenecientes a 18 especies; todas las especies se registraron anidando en los fragmentos de bosque quemado sin extracción, pero sólo ocho de ellas anidaron en los fragmentos quemados con extracción. Con sólo una excepción, la densidad de nidos de todas las especies fue mayor en los fragmentos quemados sin extracción forestal y la mitad de las especies fueron significativamente más abundantes en los fragmentos sin extracción. Todas las especies que obtienen su alimento perforando la corteza o buscando en ella fueron menos abundantes en los fragmentos con extracción, incluyendo dos de las especies más dependientes de los incendios en las Montañas Rocallosas-Picoides dorsalis y P. arcticus. Las abundancias fueron menores en los fragmentos con extracción post-incendio, a pesar de contar con un número mayor de troncos por hectárea con potencial para construir nidos, en relación con el número mínimo recomendado para mantener densidades máximas de aves que anidan en cavidades. Esto sugiere que la disminución de las densidades de los pájaros carpinteros está más relacionada con una disminución en su alimento (larvas perforadoras de escarabajos), que con la disponibilidad de sitios de anidación. Ya que se detectaron cavidades en sólo cuatro de los 244 árboles seleccionados al azar, y dado que la tasa de reutilización de cavidades por parte de las especies de anidación secundaria fue mayor en los sitios con extracción que en sitios sin extracción, la restricción de sitios de anidación puede ser un factor limitante más importante para las especies de anidación secundaria en los sitios con extracción forestal post-incendio. Estos resultados sugieren que las operaciones típicas de extracción son incompatibles con el mantenimiento de los niveles

Manuscript received 22 November 2005; accepted 15 July 2006.

${ }^{3}$ E-mail: hutto@mso.umt.edu 
endémicos de la mayoría de las poblaciones de aves que anidan en cavidades, especialmente para poblaciones de especies de anidación primaria.

\section{INTRODUCTION}

Severe, stand-replacing fire is arguably the most ecologically important disturbance agent in conifer forests of the northern Rocky Mountains (Gruell 1983, Pierce et al. 2004). These fires generally leave a mosaic of green, unburned areas interspersed with large areas of standing dead trees, or snags (Turner and Romme 1994, Turner et al. 2003). The ecological importance of this type of forest habitat is reflected in the fact that the avian community found in forests following stand-replacing fires is comprised, in part, of species (e.g., Blackbacked Woodpecker [Picoides arcticus], American Three-toed Woodpecker [Picoides dorsalis], Olive-sided Flycatcher [Contopus cooperi], and Mountain Bluebird [Sialia currucoides]) that are not only relatively abundant in, but are also relatively restricted to, severely burned forest patches (Hutto 1995, Hutto and Young 1999, Kotliar et al. 2002, Smucker et al. 2005). These species depend heavily on the abundant standing dead trees associated with severely burned forests because they provide: (1) perches from which foraging sallies are initiated, (2) food for specialized beetle larvae, which themselves serve as prey for numerous woodpecker species (Powell 2000), and (3) nesting sites (Hutto 1995).

In unburned forest, the importance of snags to cavity-nesting birds has been clearly demonstrated (Dickson et al. 1983, Marcot 1983, Scott and Oldemeyer 1983, Zarnowitz and Manuwal 1985, Schreiber and deCalesta 1992) and recommendations for snag retention during timber harvests have been incorporated into current management plans (Thomas 1979, Raphael and White 1984, Zarnowitz and Manuwal 1985, Morrison and Raphael 1993). In burned forests, however, there are still no generally accepted snag retention guidelines for postfire conditions, even though the needs of snag-dependent species in burned forests are not the same as the needs of snag-dependent species in unburned forests (Hutto 1995, 2006). The lack of snag retention guidelines for burned forests is undoubtedly a reflection of the prevailing view that forest fires are "environmental disasters" (Taylor 1995) and that such fires leave behind fire-damaged timber that, other than as salvaged wood, lacks value. Consequently, salvage logging is a common management practice in the western United States after high-severity, stand-replacing fires, as it is elsewhere in the world after severe disturbance events (Lindenmayer et al. 2004).

Because burned forests are valuable to snagdependent wildlife (and other plants and animals), and because some of these species appear to be nearly restricted in their distribution to such conditions (Hutto 1995, Hobson and Schieck 1999, Nappi 2000, Kotliar et al. 2002), managers should be especially concerned about mitigating possible negative effects of salvage logging on fire-dependent plants and animals. We need information on the effects of different levels of salvage logging to be able to assess whether any level of salvage logging is compatible with wildlife needs and, if so, which kinds and minimum numbers of snags are needed to support fire-dependent species after stand-replacing fires (Hutto 1995, 2006, Nappi et al. 2004).

Unfortunately, given the inherent danger associated with severe forest fires, the prospects of obtaining information on the effects of salvage logging from multiple, independently created experimental treatment and control plots will always be limited (Hargrove and Pickering 1992, Whelan 1995, Andersen et al. 1998, van Mantgem et al. 2001). Therefore, generalizations are most likely to emerge from meta-analyses of individual studies conducted when opportunities for study after unplanned fire events presented themselves (Kotliar et al. 2002). We capitalized on one of these rare opportunities to obtain empirical data on the effects of salvage logging when a large fire burned most of the Blackfoot-Clearwater Wildlife Management Area in western Montana. By working with the State Department of Fish, Wildlife and Parks and a local timber company, we were able to design a study that included a series of otherwise similar treatment (cut) and control (uncut) plots that allowed us to: (1) assess and compare breeding, cavity-nesting bird abundance in salvage-logged vs. unlogged burned forest patches, (2) assess and compare characteristics of nest trees and randomly 


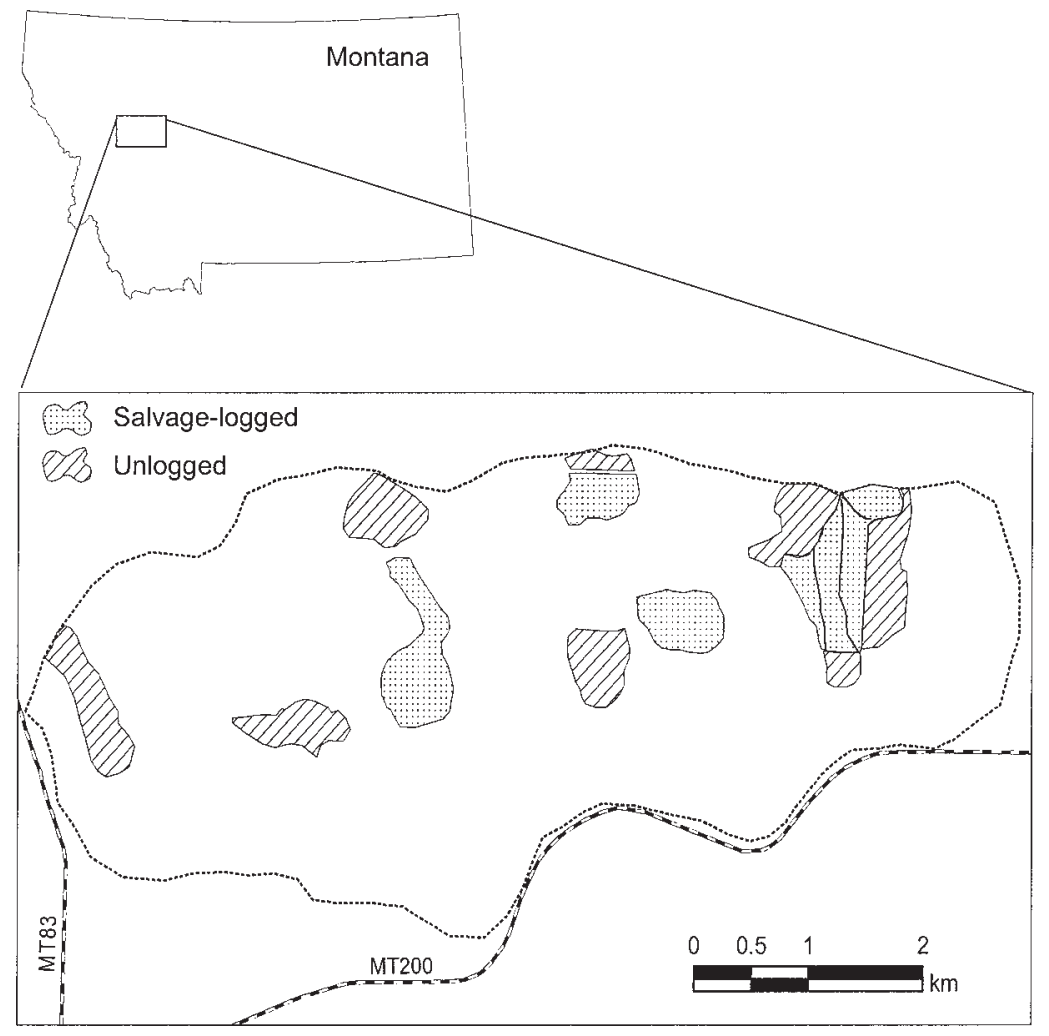

FIGURE 1. Map of the field plots used to study the effects of postfire salvage logging on cavity-nesting birds in the Blackfoot-Clearwater Wildlife Management Area, Montana. The fire boundary is indicated by the dotted line. Most of the area between plots is grassland, and MT83 and MT200 are state highways.

selected trees from salvage-logged and unlogged plots, and (3) document the reuse of cavities over a three-year period.

\section{METHODS}

\section{STUDY AREA}

This study took place on the Blackfoot-Clearwater Wildlife Management Area, which is located $80 \mathrm{~km}$ east of Missoula, Montana, at an elevation of approximately $1200 \mathrm{~m}$. A severe fire in October of 1991 burned approximately 1600 ha of grassland and mixed-conifer forest. The burned forest areas consisted mainly of 50to 150-year-old second-growth conifers (Douglas-fir [Pseudotsuga menziesii], western larch [Larix occidentalis], and ponderosa pine [Pinus ponderosa]) with occasional pockets of broadleafed deciduous trees (Populus spp.). Approximately 275 ha were salvage-logged in the winter following the fire (1991-1992) in a pattern in which seven salvage-logged plots (total- ing approximately $134 \mathrm{ha}$ ) were interspersed with eight unlogged control plots (totaling approximately 148 ha; Fig. 1). The individual plots averaged $23.9 \pm 11.7 \mathrm{SD}$ ha in size (range $=7-36 \mathrm{ha}$ ), and were delineated either on the basis of isolation of the unit or on the basis of road locations and timber harvest prescriptions provided by Champion Timber Company. The extent of salvage logging varied among plots, but in most cases all merchantable $(>15 \mathrm{~cm}$ $\mathrm{dbh},>4.5 \mathrm{~m}$ tall) fire-killed timber was removed. Most unlogged and salvage-logged forest plots were surrounded by grasslands.

\section{NEST ABUNDANCE AND CAVITY REUSE}

We located active cavity nests by searching the 15 forest plots during the breeding season from mid-May through mid-July of 1993, 1994, and 1995. We walked parallel transects (spaced at $20 \mathrm{~m}$ intervals) through the plots to systematically search the plots for active nests. Plots were of a size that required between one and 
two days' search time to cover the entire plot. We searched plots at least twice during each breeding season, and walked transects in opposite directions from visit to visit to maximize our chances of finding all active nests. Nests were located by finding cavities directly and observing subsequent activity, following adult birds to nests, or hearing young birds in the nest. We recorded activity of adult birds at the nest (building, incubating, or feeding) at the time the nest was found and the type of cavity used (excavated or natural). The first time an active nest was found, it was considered a new nest. In subsequent years, the same nest cavities were checked for activity. Cavities active in subsequent years were considered reused nests, and cavities harboring a second pair of breeding birds of the same or a different species in a single year were classified as repeat nests.

\section{VEGETATION AND TREE MEASUREMENTS}

To characterize vegetation structure associated with the two treatments, we measured vegetation characteristics surrounding 132 randomly located trees in unlogged plots and 112 randomly located trees in salvage-logged plots. Sample trees were selected by locating random grid points on high-resolution aerial photos. If a random point fell on a tree, that tree was selected as a sample tree; otherwise the point was discarded. Random points were generated until all sample trees had been identified. Sample trees were located on the ground with the aid of aerial photos.

We recorded several characteristics associated with, and vegetation conditions surrounding, nest trees and randomly selected trees. Tree characteristics included size (diameter at breast height, measured with a dbh tape), height (measured with a clinometer), species, status (live or dead; intact or with a broken or dead top), percent bark remaining (estimated visually), and presence of a nest cavity. To assess vegetation characteristics surrounding focal trees, stakes were placed $15 \mathrm{~m}$ from the tree in the four cardinal directions. We made ocular estimates of the percent of bare ground (bare soil), ground cover (herbaceous plants $<25 \mathrm{~cm}$ tall), low shrub cover (herbaceous plants $>25 \mathrm{~cm}$ tall plus woody plants $<0.5 \mathrm{~m}$ ), and tall shrub cover (woody plants $>0.5 \mathrm{~m}$ tall) in each quarter and then averaged the four estimates. These estimates were made from above, so the four estimates summed to $100 \%$. Burn severity of the vegetation within $50 \mathrm{~m}$ of a sample tree was estimated using a subjective scale of one to five (after Hutto 1995), with $1=$ $100 \%$ of the trees with green foliage or needles, $2=$ most $(>60 \%)$ trees with green foliage or needles, and most of the rest with brown needles, $3=40 \%-60 \%$ of the trees brownneedled, and the rest either green- or blackneedled, $4=$ most $(>60 \%)$ trees black-needled, and the rest with brown needles, and $5=$ all trees blackened. All vegetation measurements (including fire severity) on logged plots reflected conditions after cutting, so it was not possible to compare preharvest conditions on treatment and control plots.

\section{STATISTICAL ANALYSES}

We compared vegetation characteristics associated with the two treatments using MannWhitney $U$-tests for numerical data and chisquare likelihood ratios for categorical data. A Bonferonni correction for experiment-wise error was applied to adjust the $P$-value for multiple simultaneous tests. We tested for a difference in the distribution of nest abundance across species by treatment type using a chi-square likelihood ratio after combining numbers of nests across plots. Nest abundance was converted to nest density by averaging the number of nests per plot for each year of the study. We tested for differences in nest density over the three years of our study using repeated measures ANOVA. Nest densities were transformed by the inverse of the square root to achieve normality.

For each species with a minimum of nine nests, we compared characteristics of nest trees and randomly selected trees in both the unlogged and salvage-logged plots. Differences in numerical variables were tested with MannWhitney $U$-tests, and differences in distributions of categorical variables were tested with chi-square likelihood ratios. A Bonferonni correction for experiment-wise error was applied to all univariate tests for each species. When the same species nested in the same cavity in two or more years, the characteristics associated with that nest tree were included only once in the analysis.

For each primary cavity-nesting species, the suitability of randomly selected trees for nesting 
TABLE 1. The percentage of nests found by each of three different methods and by status at the time they were found in unlogged and salvage-logged burned forest, Montana, 1993-1995. Most nests were discovered by following adult birds to the cavity, and most had either eggs or young when they were found.

\begin{tabular}{lcc}
\hline \hline & Unlogged & $\begin{array}{c}\text { Salvage- } \\
\text { logged }\end{array}$ \\
\hline Method of location $(n=300)$ & & \\
$\quad$ Following adult bird to nest & 58 & 48 \\
$\quad$ Finding cavity directly & 21 & 23 \\
$\quad$ Seeing or hearing adult or & 21 & 29 \\
$\quad$ young at nest & & \\
Nest status $(n=392)$ & 17 & 18 \\
Building, excavating, or & & \\
$\quad$ advertising & 32 & 43 \\
$\quad$ Incubating & 51 & 39 \\
$\quad$ Feeding young & & \\
\hline
\end{tabular}

was assessed by first calculating the range of each of five characteristics associated with nest trees. If the value of a characteristic associated with a random tree fell within the range of values obtained for nest trees, that random tree was considered "suitable" for that characteristic. Overall suitability was then determined by combining suitability information from all the individual tree characteristics. If values of all characteristics of a random tree fell within the range of values from nest trees, that random tree was considered "suitable" for that species. The proportion of random trees classified as suitable for each species (all plots combined within each treatment) was then converted into an absolute number of suitable trees per hectare by multiplication with the estimated number of trees per hectare in each treatment (360 trees per ha in unlogged plots and 134 trees per ha in salvage-logged plots).

\section{RESULTS}

\section{NEST ABUNDANCE}

We found most nests between 8 and 23 June in both salvage-logged and unlogged areas. Most nests were discovered by following adult birds to the cavity, and most had either eggs or young when they were found (Table 1). Eighty-three percent of nests in unlogged plots and $77 \%$ of nests in salvage-logged plots ( $80 \%$ overall) were in cavities originally excavated by primary cavity-nesting birds.
We found 563 active nests distributed among 18 cavity-nesting species (Table 2). All 18 species nested in unlogged areas, whereas only eight species nested in salvage-logged areas (Table 2). The total number of active nests found in unlogged plots was almost three times higher than the total number of nests in salvage-logged plots, even though the area searched and search effort was similar between plot types (Table 2). The combined nest density was significantly higher in unlogged than in salvage-logged areas in each year of our study (treatment effect: $F_{1,13}=8.3, P=0.02$ ), and the mean density of all species combined increased significantly over the three years of study in both the unlogged and salvage-logged plots (year effect: $F_{2,26}=4.2, P=0.02$; Fig. 2). All cavity-nesting species except the Black-capped Chickadee (Poecile atricapillus) nested at a higher density in the unlogged than the salvage-logged areas, and half of all cavitynesting species were significantly more abundant in the unlogged plots (Table 2). The most abundant species in unlogged areas (Northern Flicker [Colaptes auratus], House Wren [Troglodytes aedon], and Mountain Bluebird) were also the most abundant in salvage-logged areas, and the vast majority of nests in both salvagelogged and unlogged plots belonged to groundand shrub-foraging species (73\% and 93\%, respectively) and to secondary cavity-nesting species $(63 \%$ and $65 \%$, respectively). Nevertheless, the relative abundances of all cavitynesting species differed significantly between the two treatments $\left(\chi_{17}^{2}=59.4, P<0.001\right)$, primarily because five timber-drilling woodpecker species and the two timber-gleaning nuthatch species nested only in the unlogged plots (Table 2).

\section{CAVITY REUSE}

Only $34 \%$ of the cavities excavated in 1993 were reused by cavity-nesting birds in 1994 (Table 3). In 1995, 36\% of cavities used for nesting during either or both of the two previous years were reused. The frequency of cavity reuse in salvage-logged areas was $50 \%$ in 1994 and $44 \%$ in 1995 . In contrast, the frequencies of reuse in unlogged areas were substantially lower-30\% in 1994 and 33\% in 1995 (Table 3). In 1995, a small percentage of cavities $(2.6 \%)$ were used twice in one breeding season, and Mountain Bluebird, House Wren, and North- 


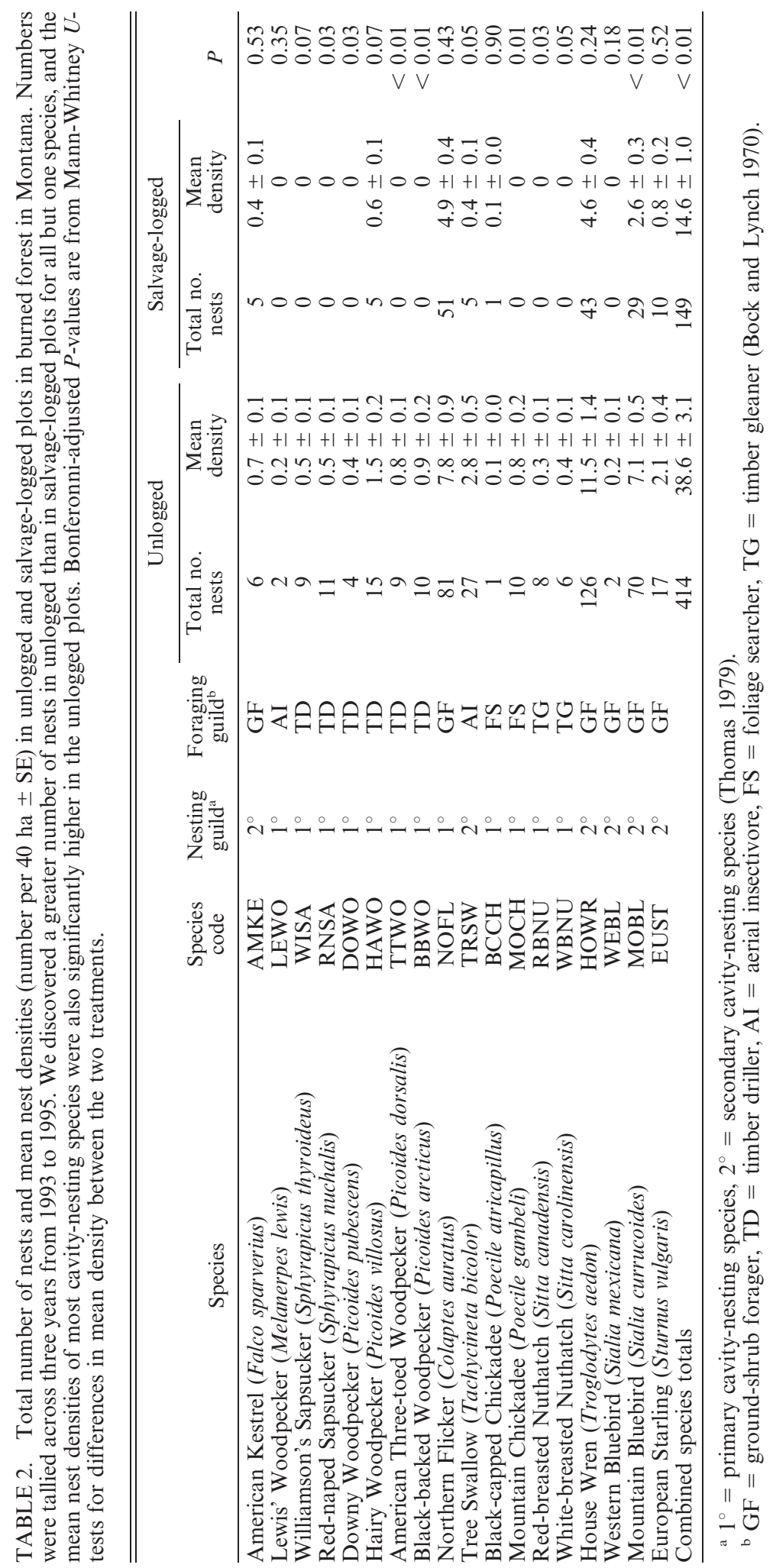




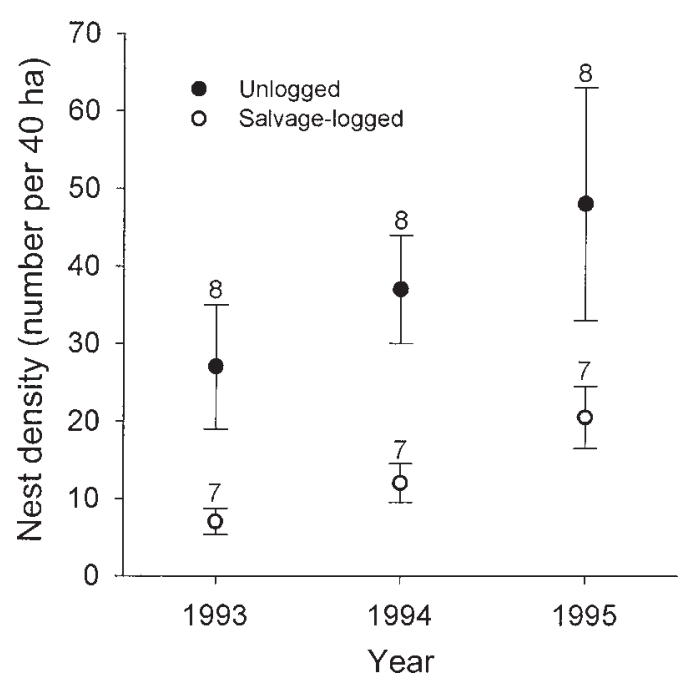

FIGURE 2. In each of the three years of study, mean nest density of all cavity-nesting species averaged over all plots was significantly higher in unlogged than in salvage-logged treatments in the Blackfoot-Clearwater Wildlife Management Area, Montana. Sample sizes appear above the error bars.

ern Flicker were the three species that most often used reused cavities for nesting. More than a quarter $(27 \%)$ of Northern Flicker nests were located in previously used cavities. Although Northern Flickers may have excavated these cavities originally, it is clear they were not creating new nest cavities each breeding season.

There were 128 cavities known by observation to have been excavated by primary cavitynesting birds. Of these, 58 were reused at least once during subsequent years, and half of those were Northern Flicker cavities being reused by flickers (Table 4). Despite the high frequency of reuse, Northern Flickers provided more cavities for other secondary cavity-nesting species than any other primary cavity-nesting species. Additionally, Northern Flicker cavities appeared to be the only cavities suitable for American Kestrels (Falco sparverius), possibly because flickers excavated relatively large entrance holes in relatively decayed snags. A small number of Red-naped (Sphyrapicus nuchalis) and Williamson's (S. thyroideus) Sapsuckers reused cavities excavated by Red-naped Sapsuckers (Table 4). Most of the Hairy (Picoides villosus), American Three-toed, and Black-backed Woodpecker cavities were reused by House Wrens and Mountain Bluebirds, which together used over a quarter of the 58 cavities originally made by primary cavity-nesting birds.

\section{VEGETATION CHARACTERISTICS}

Unlogged plots had significantly larger and taller trees, a higher density of trees, trees with more bark, higher live-tree density, and a lower proportion of intact snags than salvage-logged plots (Table 5). The burn severity surrounding randomly selected trees in unlogged plots was also slightly less than the burn severity surrounding randomly selected trees in logged plots (Table 5), although the index of severity that we used was undoubtedly affected by the removal of some green and brown-needled trees from the salvage-logged plots.

\section{CHARACTERISTICS AND AVAILABILITY OF NEST TREES}

Of the 12 species for which we found nine or more nests, all but one (Mountain Chickadee [Poecile gambeli]) nested in trees that were larger and taller than what was available in the salvage-logged plots; only the American Kestrel and Northern Flicker used larger trees than

TABLE 3. Numbers of new, reused (used in previous years by the same or different species), or repeat (used earlier in the same breeding season by the same or different species) nests across three years in unlogged and salvage-logged plots following fire in Montana. The proportion of cavities that were reused was higher in salvage-logged than in unlogged plots.

\begin{tabular}{|c|c|c|c|c|c|c|c|}
\hline \multirow[b]{2}{*}{ Year } & \multicolumn{3}{|c|}{ Unlogged } & \multicolumn{3}{|c|}{ Salvage-logged } & \multirow[b]{2}{*}{ Total } \\
\hline & $\begin{array}{l}\text { New } \\
\text { nests }\end{array}$ & $\begin{array}{c}\text { Reused } \\
\text { nests }\end{array}$ & $\begin{array}{c}\text { Repeat } \\
\text { nests }\end{array}$ & $\begin{array}{l}\text { New } \\
\text { nests }\end{array}$ & $\begin{array}{c}\text { Reused } \\
\text { nests }\end{array}$ & $\begin{array}{c}\text { Repeat } \\
\text { nests }\end{array}$ & \\
\hline 1993 & 96 & $\mathrm{~N} / \mathrm{A}$ & $\mathrm{N} / \mathrm{A}$ & 26 & N/A & N/A & 122 \\
\hline 1994 & 108 & 29 & 0 & 33 & 13 & 0 & 183 \\
\hline 1995 & 108 & 68 & 5 & 46 & 26 & 5 & 258 \\
\hline Total & 312 & 97 & 5 & 105 & 39 & 5 & 563 \\
\hline
\end{tabular}




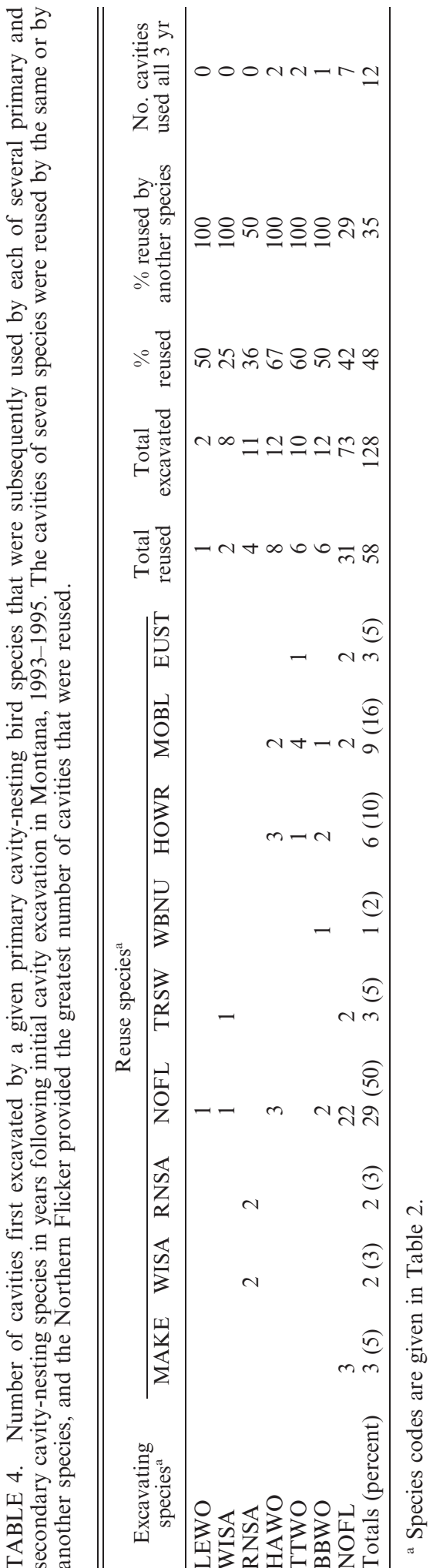

what would be expected by chance in the unlogged plots (Fig. 3). Deciduous and broken-topped trees were also used for nesting by most species more often than would be expected due to chance (Fig. 4).

The percentage of randomly selected trees that were deemed suitable for nesting varied widely among the primary cavity-nesting species (Table 6). For some species, a single tree characteristic excluded a large number of randomly selected trees from being considered suitable. For example, Red-naped Sapsuckers nested in deciduous trees only, and because deciduous trees comprised a small percentage of random trees, the proportion of suitable nest trees for sapsuckers was close to zero in both unlogged and salvage-logged areas (Table 6). The estimated density of available nest trees ranged from zero for Red-naped Sapsuckers in salvage-logged plots, to 232 trees per ha for Hairy Woodpeckers in unlogged plots (Table 6).

Nest tree availability was not as easily assessed for secondary cavity-nesters because the presence of cavities was difficult to discern and because new cavities were undoubtedly created after we measured characteristics of randomly selected trees during the first year of our study. Nevertheless, cavities were present initially in only four of 244 randomly selected trees and only in the unlogged plots.

\section{DISCUSSION}

The densities of cavity nests in this study (14.6 and 38.6 nests per 40 hectares in salvage-logged and unlogged plots, respectively) are at the upper end of cavity nest densities that have been reported for other burned areas (Bock and Lynch 1970, Taylor and Barmore 1980, Caton 1996). Nevertheless, the higher abundance and species richness of cavity-nesting birds in unlogged compared to salvage-logged burned areas in this study is a result that is consistent with virtually all studies to date on this topic (Blake 1982, Harris 1982, Raphael and White 1984, Lyon and Marzluff 1985, Caton 1996, Saab and Dudley 1998, Haggard and Gaines 2001, Morissette et al. 2002). The single exception comes from a longer-term study in ponderosa pine-dominated communities in Idaho (V. Saab, R. Russell, and J. Dudley, USDA Forest Service, unpubl. data), where the overall density of cavity-nesting birds was observed to 
TABLE 5. Vegetation characteristics associated with randomly selected trees in plots that were either unlogged ( $n=132$ trees) or salvage-logged ( $n$ $=112$ trees) after a 1991 fire in the BlackfootClearwater Wildlife Management Area, Montana. Tree sizes, tree densities, and percentage of live trees were significantly greater in unlogged than in salvagelogged plots. Means \pm SE are given for numerical variables, and frequency distributions are given for categorical variables. Asterisk indicates a significant $(P<0.05)$ difference between unlogged and salvagelogged plots.

\begin{tabular}{lcc}
\hline \hline \multicolumn{1}{c}{$\begin{array}{c}\text { Vegetation } \\
\text { characteristic }\end{array}$} & Unlogged & Salvage-logged \\
\hline DBH (cm)* & $30.7 \pm 1.1$ & $20.9 \pm 0.9$ \\
Height (m)* & $16.2 \pm 0.4$ & $12.7 \pm 0.4$ \\
Bark (\%)* & $97 \pm 1$ & $94 \pm 1$ \\
Tree species & & \\
Pinus contorta & $2 \%$ & $0 \%$ \\
Pinus ponderosa & $30 \%$ & $19 \%$ \\
Larix occidentalis & $10 \%$ & $15 \%$ \\
Pseudotsuga & $53 \%$ & $63 \%$ \\
mensiezii & & \\
Populus spp. & $5 \%$ & $3 \%$ \\
Tree status* & & \\
Intact snag & $74 \%$ & $88 \%$ \\
Broken snag & $5 \%$ & $5 \%$ \\
Broken live & $0 \%$ & $1 \%$ \\
Intact live & $21 \%$ & $6 \%$ \\
Tree density (15 m radius) & & \\
$10-40$ cm dbh* & $23.7 \pm 1.4$ & $9.1 \pm 0.8$ \\
$>40$ cm dbh* & $1.6 \pm 0.2$ & $0.0 \pm 0.0$ \\
Bare ground ( $\%)$ & $9 \pm 1$ & $8 \pm 1$ \\
Ground cover (\%) & $33 \pm 2$ & $35 \pm 2$ \\
Low shrub (\%) & $56 \pm 2$ & $55 \pm 2$ \\
Tall shrub (\%) & $3 \pm 3$ & $2 \pm 0$ \\
Burn severity* & & \\
$100 \%$ green & $18 \%$ & $2 \%$ \\
$>60 \%$ green & $5 \%$ & $3 \%$ \\
$40 \%-60 \%$ brown & $25 \%$ & $9 \%$ \\
$>60 \%$ black & $24 \%$ & $25 \%$ \\
$100 \%$ black & $28 \%$ & $62 \%$ \\
\hline & & \\
\hline
\end{tabular}

be slightly greater in salvage-logged plots in the first five years following fire, but not during the next five years. The combined density of all cavity-nesting birds increased over the threeyear period of this study, primarily due to the creation of cavities by primary cavity-nesting species and the use of those same cavities in subsequent years by both primary and secondary cavity-nesters.

Of particular note is the fact that six of eight woodpecker species nested only in unlogged burned forest; they were entirely absent from salvage-logged areas. This is consistent with reports (Hutto 1995, Hutto and Young 1999) that, in the northern Rocky Mountains, two of these species (Black-backed and American Three-toed Woodpeckers) are not only more abundant in burned conifer forests than in any other vegetation type, but are also relatively restricted to such conditions. This result is also consistent with results from all of the previously cited studies on the effects of salvage logging on cavity-nesting birds. The number of Blackbacked and American Three-toed Woodpecker nests decreased from the third to the fifth year after fire, which is similar to what Harris (1982), Caton (1996), Saab et al. (2004) and Saab et al. (V. Saab, R. Russell, and J. Dudley, USDA Forest Service, unpubl. data) found in their multiyear studies of postfire forests.

Preharvest tree density in salvage-logged areas (estimated by adding stump density to existing tree density) was 271 trees per ha, which was still well below the tree density in unlogged areas (360 trees per ha). It is therefore likely that salvage-logged and unlogged areas were somewhat different prior to the onset of fire and subsequent salvage-logging. There is always the possibility that some preharvest difference between plot types (e.g., a difference in average fire severity, slope, or aspect) might have contributed to the differences in bird densities between plot types; however, the presence of treatment replication in this study and the complete agreement between our results and the results of others who have looked at the effects of salvage logging strongly suggest that the significant reduction in abundance of cavity-nesting timber-drillers and timber-gleaners in salvage-logged areas was due primarily to the reduction in number of recently killed snags. This raises the question of whether it was a reduction in number of potential nest sites or some other aspect of habitat quality such as food availability that was affected most by the removal of standing dead trees.

Snags have traditionally been viewed as valuable for cavity-nesting birds exclusively in terms of their potential to be used as nest sites. Indeed, snag-management guidelines were originally based on meeting the nesting requirements of cavity-nesting birds (Thomas 1979). If nest trees were limiting bird densities in salvagelogged plots, then the density of suitable nest trees should have decreased to a number well below 6-8 trees per ha-the minimum number believed necessary to support maximum population densities of most cavity-nesting species 

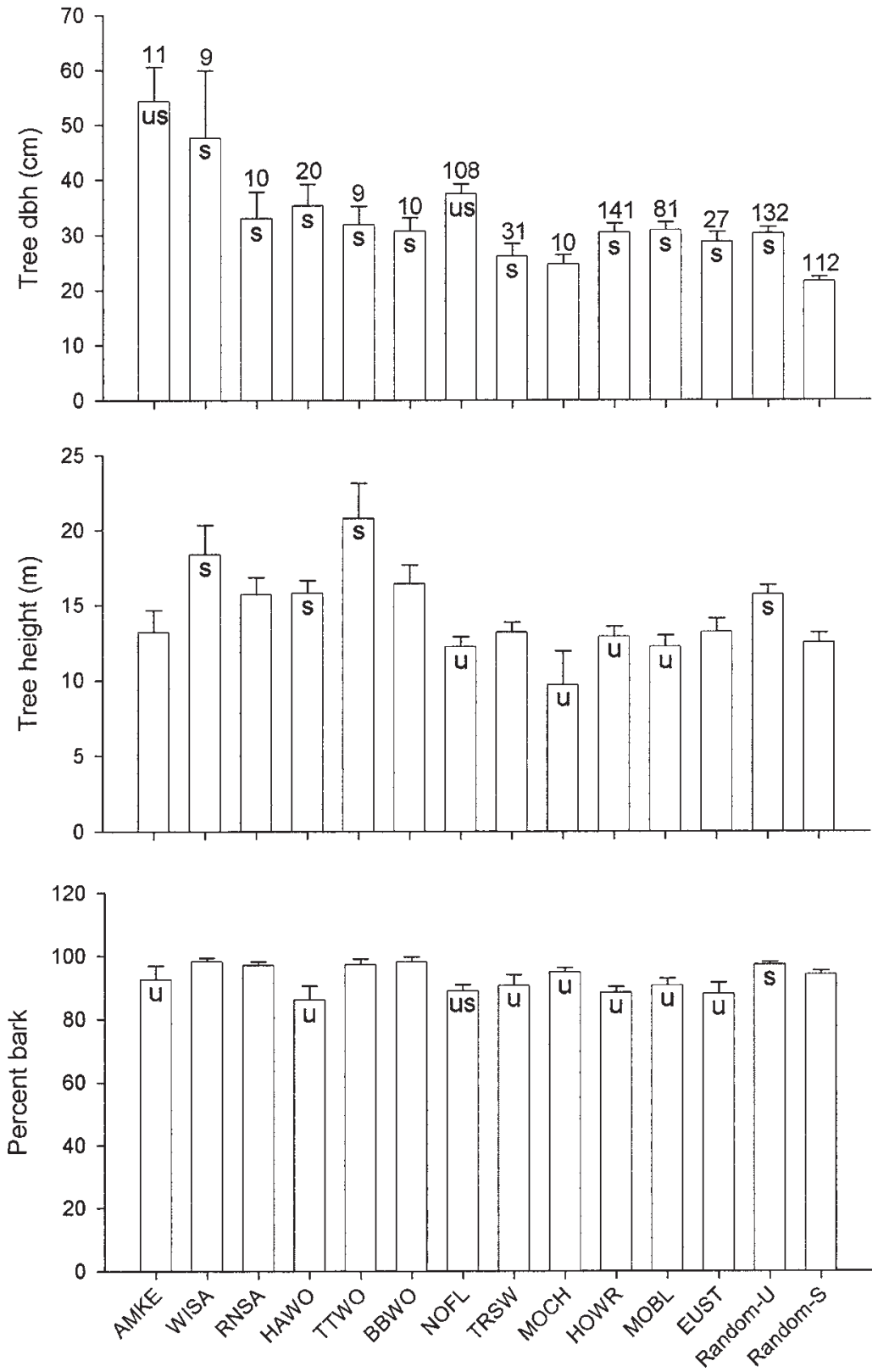

FIGURE 3. Mean nest tree characteristics ( \pm SE) for cavity-nesting bird species (codes given in Table 2$)$ and for randomly selected trees in unlogged (Random-U) and salvage-logged (Random-S) plots in the BlackfootClearwater Wildlife Management Area, Montana. Nest trees generally differed significantly in one or more respects from randomly selected trees, especially in salvage-logged plots. Sample sizes are given above bars in the upper bar chart. Small letters indicate significant differences from randomly selected trees in salvagelogged (s) or unlogged (u) plots $(P<0.05$, Mann-Whitney $U$-tests with Bonferonni correction for multiple comparisons).

(Thomas 1979:appendices 22, 23). We tested this hypothesis by calculating the percentage of randomly selected trees in both uncut and salvage-logged plots that could be considered suitable for nesting by each species. Most cavity-nesting species used snags rather than 

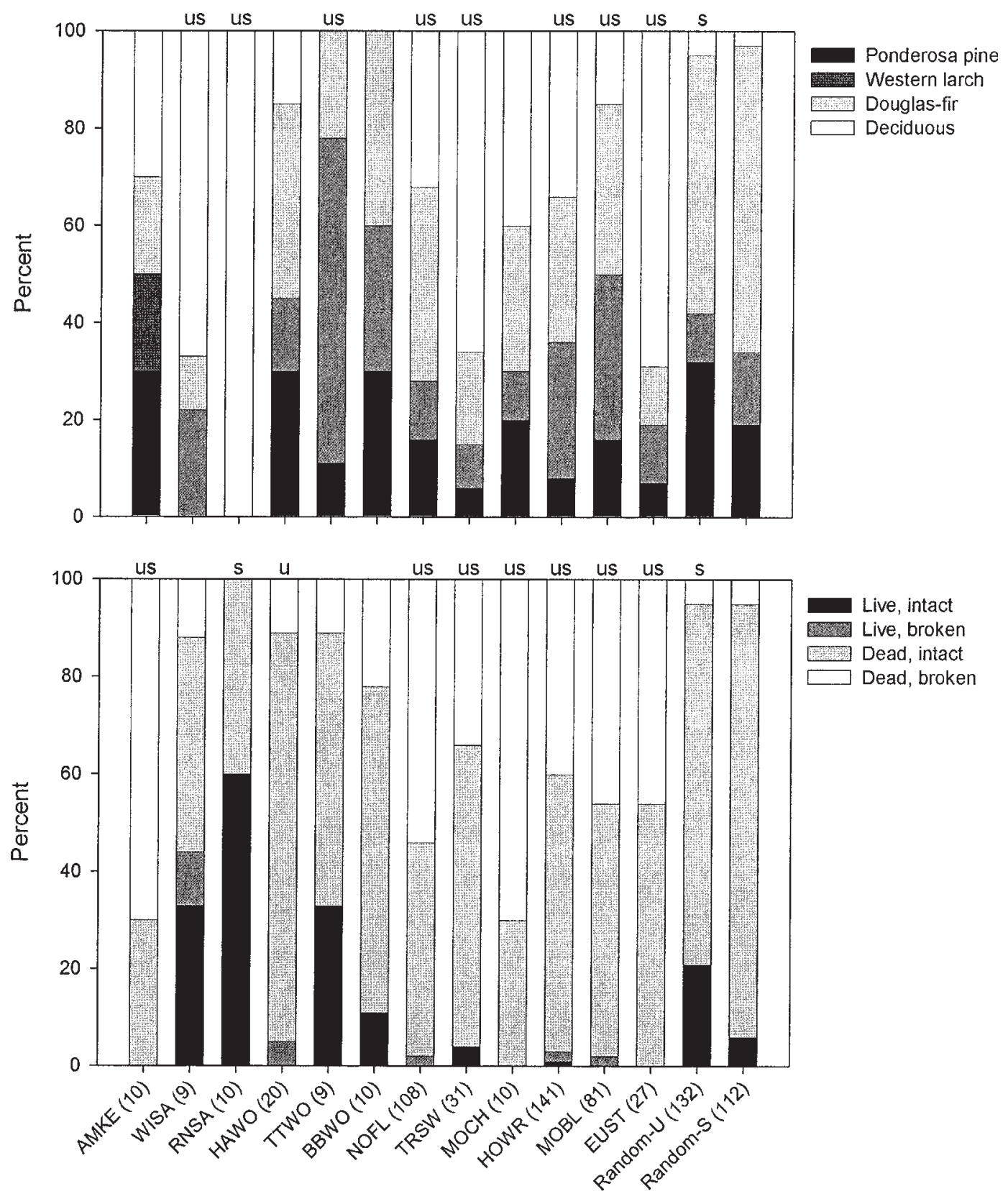

FIGURE 4. Frequency distributions of tree species and status of trees used by cavity-nesting bird species (codes given in Table 2) and of randomly selected trees in unlogged (Random-U) and salvage-logged (Random-S) plots. Most cavity-nesters used deciduous trees and broken-topped snags more than expected due to chance. Sample sizes are given at the bottom of the figure. Small letters indicate significant differences from randomly selected trees in salvage-logged (s) or unlogged $(\mathrm{u})$ plots $(P<0.05$, chi-square likelihood ratio with Bonferonni correction for multiple comparisons).

live trees for nesting, and several species used broken-topped snags more than expected based on their availability. All but one species
(Mountain Chickadee) used nest trees that had significantly larger diameters than randomly selected trees in salvage-logged areas. The 
TABLE 6. Percentages of randomly selected trees in unlogged $(n=132)$ and salvage-logged $(n=112)$ plots that were considered suitable for primary cavity-nesting species according to each of five different tree characteristics and all five characteristics combined in unlogged (U) and salvage-logged (S) plots in burned forest in Montana, 1993-1995. See Table 2 for Latin names of bird species. Only species with at least nine nests were included. The density of potentially suitable nest trees for each species was much greater in unlogged plots, and was greater than the minimum density needed to support maximum population densities of most cavity-nesting species in both unlogged and salvage-logged plots.

\begin{tabular}{|c|c|c|c|c|c|c|c|c|c|c|c|c|c|c|c|}
\hline \multirow[b]{3}{*}{ Species } & \multirow[b]{3}{*}{$n$} & \multicolumn{12}{|c|}{ Tree characteristic } & \multirow{2}{*}{\multicolumn{2}{|c|}{$\begin{array}{l}\text { Estimated } \\
\text { number per ha }\end{array}$}} \\
\hline & & \multicolumn{2}{|c|}{$\mathrm{DBH}$} & \multicolumn{2}{|c|}{ Height } & \multicolumn{2}{|c|}{ Bark } & \multicolumn{2}{|c|}{ Status } & \multicolumn{2}{|c|}{ Species } & \multicolumn{2}{|c|}{$\overline{\text { Combined }}$} & & \\
\hline & & $\mathrm{U}$ & $\bar{S}$ & $\mathrm{U}$ & $\bar{S}$ & $\mathrm{U}$ & $\bar{S}$ & $\mathrm{U}$ & $\bar{S}$ & $\mathrm{U}$ & $\bar{S}$ & $\mathrm{U}$ & $S$ & $\mathrm{U}$ & $S$ \\
\hline $\begin{array}{r}\text { Williamson's } \\
\text { Sapsucker }\end{array}$ & 9 & 67 & 21 & 93 & 94 & 95 & 92 & 99 & 99 & 68 & 81 & 39 & 10 & 142 & 14 \\
\hline Red-naped Sapsucker & 10 & 60 & 26 & 67 & 70 & 95 & 92 & 95 & 94 & 5 & 3 & 3 & 0 & 11 & 0 \\
\hline $\begin{array}{l}\text { American Three-toed } \\
\text { Woodpecker }\end{array}$ & 9 & 73 & 31 & 67 & 31 & 96 & 92 & 100 & 99 & 93 & 97 & 48 & 11 & 172 & 14 \\
\hline $\begin{array}{l}\text { Black-backed } \\
\text { Woodpecker }\end{array}$ & 10 & 58 & 21 & 85 & 77 & 98 & 93 & 100 & 99 & 97 & 93 & 48 & 14 & 172 & 19 \\
\hline Hairy Woodpecker & 20 & 99 & 87 & 85 & 77 & 98 & 96 & 78 & 93 & 100 & 100 & 64 & 63 & 232 & 84 \\
\hline Northern Flicker & 108 & 91 & 61 & 99 & 100 & 79 & 93 & 99 & 99 & 100 & 100 & 62 & 53 & 224 & 71 \\
\hline Mountain Chickadee & 10 & 52 & 38 & 80 & 96 & 95 & 92 & 99 & 100 & 78 & 93 & 36 & 41 & 128 & 55 \\
\hline
\end{tabular}

selective removal of economically valuable larger-diameter trees clearly reduced the density and average size of snags in salvage-logged areas and, therefore, reduced the amount of suitable nesting habitat. Nevertheless, the decline in density of snags that might be used as nest sites by those bird species that were most negatively affected by logging still far exceeded the 6-8 snags per ha recommended as a minimum number needed to maintain maximum population densities.

These results highlight the fact that we need to appreciate snags as food resources as well as nest-site resources and that, for timber-drilling woodpecker species in particular, the number of snags needed to meet food resource needs appears to be much greater than the number needed to meet nesting requirements. Most woodpecker species in this study are relatively "tree-dependent" foragers because they forage on dead trees for beetle larvae. Burned snags are known to serve as sources of superabundant bark and wood-boring beetle larvae (Muona and Rutanen 1994, Rasmussen et al. 1996, Hart 1998), which are the primary food resource for tree-dependent foragers in burned forests (Powell et al. 2002, Nappi et al. 2003). Salvage logging undoubtedly reduces foraging opportunities for these birds, and may be the primary reason that overall habitat suitability declines for them (Caton 1996). The total disappearance of most timber-drilling and timber-gleaning birds in this study also underscores the need for a modification of current snag management guidelines (Hutto 2006) to better recognize the importance of retaining numerous snags as sources for food (beetle larvae) in burned forests.

In contrast with primary cavity-nesting birds, secondary cavity-nesters are often thought to be limited by the availability of nest sites (Brush 1983, Brawn and Balda 1988, Walankiewicz 1991). Because two-thirds of the cavities we discovered were not reused during the three years of this study, either something other than nest sites limited the density of secondary cavity-nesting birds, or many of the apparently suitable nest cavities were not really suitable at all (see also Welsh and Capen 1992). Other animals (e.g., northern flying squirrels [Glaucomys sabrinus] and red squirrels [Tamiasciurus hudsonicus]) were observed using previously active cavities, and they are known to displace secondary cavity-nesting birds or depredate their nests. The location of cavities near other nesting birds of the same or different species may also make cavities unsuitable for nesting. For example, birds may avoid nesting near American Kestrel nests because they (or their nestlings) might experience higher rates of predation. Indeed, American Kestrels were observed to prey on other secondary cavitynesting species in this study. Other predators known to occur in the study area, and that 
could have affected the suitability of cavities for secondary cavity-nesters, include striped skunks (Mephitis mephitis), black bears (Ursus americana), and weasels (Mustela spp.). Other factors such as a lack of foraging opportunities could also limit secondary cavity-nesting bird densities in the face of what appear to be abundant nesting opportunities.

Assuming that secondary cavity-nesters are limited by nesting opportunities, it is noteworthy that the frequency of cavity reuse was higher in salvage-logged than in unlogged plots, possibly reflecting a greater level of nest-site limitation in the salvage-logged areas. More than $80 \%$ of the nests of secondary cavitynesters were located in cavities excavated by woodpeckers, indicating a strong reliance on primary cavity-nesting birds for cavity excavation (see also Dobkin et al. 1995). In unlogged areas, the continuous creation of roosting and nesting cavities by primary cavity-nesting species may provide abundant new cavities for secondary cavity-nesting birds to use. In contrast, fewer breeding primary cavity-nesters in salvage-logged areas create fewer new cavities, and this may force secondary cavity-nesting birds to reuse a smaller number of older cavities, which could also affect their nest success in salvage-logged forests.

In conclusion, the cavity-nesting bird community as a whole was clearly negatively affected by salvage logging in our study area in the early years following stand-replacing fire, and the main problem for primary cavitynesting bird species does not appear to have been availability of snags as nest sites. Rather, the reduction in numbers of trees that harbored important food resources seemed to be to the detriment of the most fire-dependent cavitynesting bird species. Especially noteworthy was the absence of several postfire specialist woodpecker species from salvage-logged areas and the general decrease in nesting densities of timber-drilling and timber-gleaning species compared to their densities in unlogged burned areas. These results are especially important in light of recent modifications to legislation and regulations by provincial governments in $\mathrm{Ca}$ nada (cited in Nappi et al. 2003) and by the U. S. government (Healthy Forests Restoration Act of 2003) to expedite and provide incentives for salvage logging on top of already documented increases in dead tree harvest in the West
(Duncan 2002). Because early postfire cavitynesting bird communities are biologically unique, and because we lose the most firedependent elements of that community through salvage harvests such as the ones included in this study, the merit of postfire salvage logging should be reexamined, especially when there are other, less ecologically sensitive options available for timber harvest. Although research on the effects of different levels and styles of salvage logging are urgently needed, the findings that have already emerged from this and from other studies (McIver and Starr 2000, Kotliar et al. 2002, Beschta et al. 2004, Karr et al. 2004) are entirely consistent, and they suggest that it may be difficult to retain the ecological integrity of a burned forest in the face of most kinds of postfire salvage logging.

\section{ACKNOWLEDGMENTS}

We thank two anonymous reviewers, David Dobkin, Sallie Hejl, Paul Alaback, Elaine Caton, Vita Wright, and Jock Young for comments on earlier drafts of this paper. Financial assistance for this study was provided by a McIntire-Stennis grant from the University of Montana College of Forestry and Conservation and a student research grant from the North American Bluebird Society. Generous in-kind support was provided by the Montana Department of Fish, Wildlife and Parks, Champion Timber Company, and Richard Howe. Special thanks to Mike Thompson at Montana Fish, Wildlife and Parks for his help through all phases of this project and to Ann Mull for field assistance.

\section{LITERATURE CITED}

Andersen, A. N., R. W. Braithwaite, G. D. Cook, L. K. Corbett, R. J. Williams, M. M. Douglas, A. M. Gill, S. A. SETterfield, AND W. J. Muller. 1998. Fire research for conservation management in tropical savannas: introducing the Kapalga fire experiment. Australian Journal of Ecology 23:95-110.

Beschta, R. L., J. J. Rhodes, J. B. Kauffman, R. E. Gresswell, G. W. Minshall, J. R. KarR, D. A. Perry, F. R. Hauer, and C. A. FRISSELL. 2004. Postfire management on forested public lands of the western United States. Conservation Biology 18:957-967.

BLAKE, J. G. 1982. Influence of fire and logging on nonbreeding bird communities of ponderosa pine forests. Journal of Wildlife Management 46:404-415.

Bock, C. E., AND J. F. LYNCH. 1970. Breeding bird populations of burned and unburned conifer forest in the Sierra Nevada. Condor 72:182-189.

Brawn, J. D., AND R. P. BALdA. 1988. Population biology of cavity nesters in northern Arizona: do 
nest sites limit breeding densities? Condor 90:61-71.

BRUSH, T. 1983. Cavity use by secondary cavitynesting birds and response to manipulations. Condor 85:461-466.

CAton, E. L. 1996. Effects of fire and salvage logging on the cavity-nesting bird community in northwestern Montana. M.Sc. thesis, University of Montana, Missoula, MT.

Dickson, J. G., R. N. CONNER, AND J. H. WilliamSON. 1983. Snag retention increases birds in a clearcut. Journal of Wildlife Management 47:799-809.

Dobkin, D. S., A. C. Rich, J. A. Pretare, and W. H. PYLE. 1995. Nest-site relationships among cavity-nesting birds of riparian and snowpocket aspen woodlands in the northwestern Great Basin. Condor 97:694-707.

Duncan, S. 2002. Postfire logging: is it beneficial to a forest? Science Findings 47:1-5.

GRUELL, G. E. 1983. Fire and vegetative trends in the northern Rockies: interpretations from 18711982 photographs. USDA Forest Service General Technical Report INT-158.

HAGGARD, M., AND W. L. GAINES. 2001. Effects of stand-replacement fire and salvage logging on a cavity-nesting bird community in eastern Cascades, Washington. Northwest Science 75: 387-396.

Hargrove, W. W., And J. Pickering. 1992. Pseudoreplication: a sine qua non for regional ecology. Landscape Ecology 6:251-258.

HARRIS, M. A. 1982. Habitat use among woodpeckers in forest burns. M.Sc. thesis, University of Montana, Missoula, MT.

HART, S. 1998. Beetle mania: an attraction to fire. BioScience 48:3-5.

Hobson, K. A., And J. SchiEck. 1999. Changes in bird communities in boreal mixedwood forest: harvest and wildfire effects over 30 years. Ecological Applications 9:849-863.

HutTo, R. L. 1995. The composition of bird communities following stand-replacement fires in northern Rocky Mountain (U.S.A.) conifer forests. Conservation Biology 9:1041-1058.

Hutto, R. L. 2006. Toward meaningful snagmanagement guidelines for postfire salvage logging in North American conifer forests. Conservation Biology 20:984-993.

Hutto, R. L., AND J. S. Young. 1999. Habitat relationships of landbirds in the Northern Region, USDA Forest Service. USDA Forest Service General Technical Report RMRSGTR-32.

KarR, J. R., J. J. Rhodes, G. W. Minshall, F. R. Hauer, R. L. Beschta, C. A. Frissell, AND D. A. Perry. 2004. The effects of postfire salvage logging on aquatic ecosystems in the American West. BioScience 54:1029-1033.

Kotliar, N. B., S. J. Hejl, R. L. Hutto, V. A SaAB, C. P. Melcher, And M. E. McFadzen. 2002. Effects of fire and post-fire salvage logging on avian communities in conifer-dominated forests of the western United States. Studies in Avian Biology 25:49-64.
Lindenmayer, D. B., D. R. Foster, J. F. Frank Lin, M. L. Hunter, R. F. Noss, F. A. Schmiegelow, AND D. Perry. 2004. Salvage harvesting policies after natural disturbance. Science 303:1303.

LYON, L. J., AND J. M. MARZluff. 1985. Fire's effects on a small bird population, p. 16-22. In J. E. Lotan and J. K. Brown [EDS.], Fire's effects on wildlife habitat-symposium proceedings. USDA Forest Service General Technical Report INT186.

Marcot, B. G. 1983. Snag use by birds in Douglasfir clearcuts, p. 134-139. In J. W. Davis, G. A. Goodwin, and R. A. Ockenfels [EDS.], Snag habitat management: proceeding of the symposium. USDA Forest Service General Technical Report RM-99.

MCIVER, J. D., AND L. StARR. 2000. Environmental effects of postfire logging: literature review and annotated bibliography. USDA Forest Service General Technical Report PNW-GTR-486.

Morissette, J. L., T. P. CobB, R. M. Brigham, AND P. C. JAMES. 2002. The response of boreal forest songbird communities to fire and post-fire harvesting. Canadian Journal of Forest Research 32:2169-2183.

MorRison, M. L., AND M. G. RAPHAEL. 1993. Modeling the dynamics of snags. Ecological Applications 3:322-330.

MuONA, J., AND I. RutANEN. 1994. The short-term impact of fire on the beetle fauna in boreal coniferous forest. Annales Zoologici Fennici 31:109-121.

NAPPI, A. 2000. Distribution des pics et utilisation des arbres morts dans les forêts soumises aux perturbations naturelles en pessière à mousses. M.Sc. thesis, Université du Québec, Montreal, Quebec.

Nappi, A., P. Drapeau, J.-F. Giroux, And J.-P. SAVARD. 2003. Snag use by foraging Blackbacked Woodpeckers (Picoides arcticus) in a recently burned eastern boreal forest. Auk 120: 505-511.

NAPPI, A., P. DRAPEAU, AND J.-P. L. SAVARd. 2004. Salvage logging after wildfire in the boreal forest: is it becoming a hot issue for wildlife? Forestry Chronicle 80:67-74.

Pierce, J. L., G. A. Meyer, And A. J. T. Jull. 2004. Fire-induced erosion and millennial-scale climate change in northern ponderosa pine forests. Nature 432:87-90.

Powell, H. 2000. The influence of prey density on post-fire habitat use of the Black-backed Woodpecker. M.Sc. thesis, University of Montana, Missoula, MT.

Powell, H. D. W., S. J. HeJl, AND D. L. SiX. 2002. Measuring woodpecker food: a simple method for comparing wood-boring beetle abundance among fire-killed trees. Journal of Field Ornithology 73:130-140.

RAPHAEL, M. G., AND M. White. 1984. Use of snags by cavity-nesting birds in the Sierra Nevada. Wildlife Monographs 86.

Rasmussen, L. A., G. D. Amman, J. C. VandyGRIFF, R. D. OAKes, A. S. Munson, AND K. E. 
GIBSON. 1996. Bark beetle and wood borer infestation in the Greater Yellowstone area during four postfire years. USDA Forest Service Research Paper INT-RP-487.

SAAB, V. A., J. Dudley, AND W. L. Thompson. 2004. Factors influencing occupancy of nest cavities in recently burned forests. Condor 106:20-36.

SAab, V. A., AND J. G. Dudley. 1998. Responses of cavity-nesting birds to stand-replacement fire and salvage logging in ponderosa pine/Douglasfir forests of southwestern Idaho. USDA Forest Service Research Paper RMRS-RP-11.

SChreIBER, B., AND D. S. DECALESTA. 1992. The relationship between cavity-nesting birds and snags on clearcuts in western Oregon. Forest Ecology and Management 50:299-316.

ScotT, V. E., AND J. L. OldeMEYeR. 1983. Cavitynesting bird requirements and responses to snag cutting, p. 19-23. In J. W. Davis, G. A. Goodwin, and R. A. Ockenfels [EDS.], Snag habitat management: proceeding of the symposium. USDA Forest Service General Technical Report RM-99.

Smucker, K. M., R. L. Hutto, and B. M. Steele. 2005. Changes in bird abundance after wildfire: importance of fire severity and time since fire. Ecological Applications 15:1535-1549.

TAYLOR, C. 1995. The politics of salvage timber. Journal of Forestry 93:60.

TAYlOR, D. L., AND W. J. BARMORE. 1980. Post-fire succession of avifauna in coniferous forests of Yellowstone and Grand Teton National Parks, Wyoming, p. 130-145. In R. M. DeGraaf [ED.],
Workshop proceedings: management of western forests and grasslands for nongame birds. USDA Forest Service General Technical Report INT86.

ThomAs, J. W. 1979. Wildlife habitats in managed forests: the Blue Mountains of Oregon and Washington. Agriculture Handbook No. 553, USDA Forest Service, Washington, DC.

Turner, M. G., AND W. H. Romme. 1994. Landscape dynamics in crown fire ecosystems. Landscape Ecology 9:59-77.

Turner, M. G., W. H. Romme, AND D. B. Tinker. 2003. Surprises and lessons from the 1988 Yellowstone fires. Frontiers in Ecology and the Environment 1:351-358.

van Mantgem, P., M. Schwartz, And M. B. KEIFER. 2001. Monitoring fire effects for managed burns and wildfires: coming to terms with pseudoreplication. Natural Areas Journal 21: 266-273.

Walankiewicz, W. 1991. Do secondary cavitynesting birds suffer more from competition for cavities or from predation in a primeval deciduous forest? Natural Areas Journal 11:203-212.

Welsh, C. J. E., AND D. E. CAPEN. 1992. Availability of nesting sites as a limit to woodpecker populations. Forest Ecology and Management 48:31-41.

Whelan, R. J. 1995. The ecology of fire. Cambridge University Press, New York.

Zarnowitz, J. E., AND D. A. Manuwal. 1985. The effects of forest management on cavity-nesting birds in northwestern Washington. Journal of Wildlife Management 49:255-263. 